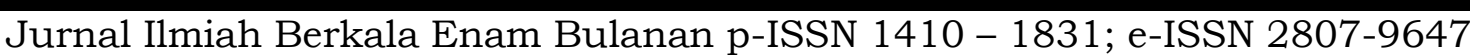 JURNAL AKUNTANSI DAN KEUANGAN

\section{ANALISIS KINERJA NON FINANCIAL TERHADAP KEPUASAN KERJA DAN PRESTASI KERJA}

\author{
Chara Pratami Tidespania Tubarad ${ }^{1}$ \\ ${ }^{1}$ Fakultas Ekonomi dan Bisnis Universitas Lampung
}

\section{Informasi Naskah}

Update Naskah:

Dikumpulkan: 30 Mei 2019;

Diterima: 30 Juni 2019;

Terbit/Dicetak: 30 Juli 2019

\section{Keywords:}

Kinerja Non Financial, Prestasi Kerja, Kepuasan Kerja

\section{$\underline{\text { Abstract }}$}

Nowadays the performance of Civil Servants (PNS) related to service to the community has always been the spotlight. The low work discipline, awareness, and service shown by some of the Civil Servants has an impact on negative stereotypes provided by the community. Therefore there is a need for significant improvements so the performance of government employees can be as expected. Because undisciplined work behavior can result in a reduction in the performance of Civil Servants in general, especially in the Lampung Regional, coupled with negative opinions from the public because in the presentation of financial statements they cannot be accountable and timely. Non-financial performance affects work performance and job satisfaction affects work performance. 


\section{A. PENDAHULUAN}

Untuk meningkatkan kepuasan berbagai pihak maka perusahaan perlu melakukan perencanaan yang terintegrasi dan terkoordinasi dalam upaya memuaskan berbagai pihak dan tetap selaras dengan strategi perusahaan untuk mencapai visi dan misi yang telah ditetapkan perusahaan sebelumnya. Salah satu cara yang dapat dilakukan adalah dengan melakukan perencanaan pengukuran kinerja finansial dan kinerja non finansial yang bisa mengetahui sampai sejauh mana tingkat kepuasan berbagai pihak telah terpenuhi.

Penelitian yang dilakukan Maisel (1996) menunjukkan bahwa perusahaan lebih menitikberatkan pada penekanan pengukuran finansial dibanding dengan businnes performance dan organizational Effectiveness. Ukuran finansial yang diteliti dalam penelitian tersebut adalah sales growth and profitability, product cost and margin, EPS, ROA, dan ROI. Hal ini menunjukkan sebagian besar perusahaan ternyata menganggap ukuran finansial lebih penting atau lebih ditekankan. Pengukuran finansial pada dasarnya lebih objektif walaupun kurang diperhitungkan didalan pengambilan keputusan.

Untuk meningkatkan kinerja pada organisasi, dibutuhkan sistem pengukuran kinerja yang nantinya akan berfungsi sebagai pemberi informasi dimana dapat menjadi acuan para manajer dalam mengambil suatu keputusan yang tepat demi kemajuan perusahaan umumnya, pengukuran kinerja suatu perusahaan dapat dilihat dari segi keuangan dan dari segi non-keuangan. Kinerja non keuangan tidak kalah penting karena dapat digunakan sebagai alat pelengkap informasi untuk mengukur kinerja karyawan yang dibutuhkan para manajer. Sistem pengukuran kinerja dapat memberikan kejelasan tugas dengan memberikan pemahaman yang jelas kepada karyawan mengenai kinerja, dampak suatu tindakan, dan hubungan antar bagian yang berbeda dalam operasional perusahaan. Sehingga dapat dikatakan bahwa sistem pengukuran kinerja dapat memberikan informasi yang jelas kepada karyawan mengenai apa yang menjadi tanggung jawab kerjanya. Dalam pengukuran kinerja keuangan dan keuangan mempunyai dampak terhadap kepuasan kerja yang dapat mendorong presetasi kerja karyawan. Dengan kepuasan kerja yang diperoleh, diharapkan kinerja yang tinggi dapat dicapai para pegawai. Sehingga dapat diketahui bahwa tidak hanya kemampuan pegawai saja yang diperlukan dalam bekerja tetapi juga tingkat kepuasan dalam bekerja sangat mempengaruhi pegawai untuk menghasilkan kinerja yang lebih baik.

Selama ini kinerja dari pegawai pemerintahan (PNS) terkait pelayanan kepada masyarakat selalu menjadi sorotan. Rendahnya kedisiplinan kerja, kesadaran, serta pelayanan yang ditunjukkan oleh sebagian kalangan pegawai pemerintahan tersebut berdampak pada streotip negatif yang diberikan oleh masyarakat. Oleh sebab itu perlu adanya pembenahan-pembenahan signifikan agar kinerja pegawai pemerintahan dapat sesuai dengan yang diharapkan. Dalam rangka memberikan pelayanan pada masyarakat termasuk juga di dalamnya menyajikan laporan keuangan instansi yang akuntabel dan tepat waktu. Pada PMK Nomor 177/PMK.05 Tahun 2015 tentang pedoman penyusunan laporan keuangan kementerian/lembaga kinerja pegawai khususnya bendahara dan staf keuangan dituntut harus disiplin dalam menyusun dan menyajikan laporan keuangan sesuai dengan peraturan tersebut, karena Perilaku bekerja yang tidak disiplin dapat mengakibatkan berkurangnya kinerja Pegawai Negeri Sipil secara umumnya, ditambah dengan pendapat negatif dari masyarakat karena dalam penyajian laporan keuangannya tidak dapat akuntabel dan tepat waktu. Peningkatan kedisiplinan pegawai harus terus ditingkatkan demi birokrasi pemerintahan yang lebih baik dalam rangka pelayanan terhadap masyarakat.

\section{B. LANDASAN TEORI DAN PENGEMBANGAN HIPOTESIS}

\section{Pengukuran Kinerja}

Pengukuran kinerja adalah proses penilaian kemajuan pekerjaan terhadap tujuan dan sasaran yang telah ditentukan sebelumnya, termasuk efisiensi penggunaan sumber daya dalam menghasilkan barang dan jasa; kualitas barang dan jasa (seberapa baik barang dan jasa diserahkan kepada pelanggan dan sampai seberapa jauh pelanggan terpuaskan); hasil kegiatan dibandingkan dengan maksud yang diinginkan, dan efektivitas tindakan dalam mencapai tujuan (Robertson, 2002 dalam Mahsun, 2006: 25).

Dari definisi- definisi tersebut dapat disimpulkan bahwa pengukuran kinerja adalah tindakan 
pengukuran yang dilakukan terhadap berbagai aktivitas dalam rantai nilai yang ada pada perusahaan (Yuwono, 2004:23).

\section{Kepuasan Kerja}

Menurut As'ad (2008) bahwa kepuasan kerja yang sederhana dan operasional adalah perasaan seseorang terhadap pekerjaan.Ini berarti bahwa konsepsi kepuasan kerja semacam ini melihat kepuasan kerja itu sebagai hasil interaksi manusia dengan lingkungan kerjanya.Jadi determinasi kepuasan kerja menurut batasan ini meliputi perbedaan individu (individual differences) maupun situasi lingkungan pekerjaan.Di samping itu, perasaan orang terhadap pekerjaan tentulah sekaligus merupakan refleksi dari sikapnya terhadap pekerjaan.

Luthans (2005:243) menyebutkan ada 5 dimensi kepuasan kerja, yaitu:

a. The work itself, karyawan cenderung lebih menyukai pekerjaan-pekerjaan yang menarik, kesempatan untuk belajar, dan kesempatan untuk menerima tanggung jawab yang lebih besar.

b. Supervision, supervisi yang adil, terbuka dan mau bekerjasama dengan bawahan akan mempengaruhi karyawan dalam bekerja.

c. Coworkers, rekan kerja atau tim yang kooperatif merupakan sumber kepuasan kerja, tim yang "kuat" menjadi sumber dukungan, kenyamanan, nasihat dan bantuan bagi karyawan.

d. Pay, sistem pemberian upah yang didasarkan pada tuntutan pekerjaan, tingkat ketrampilan individu, dan standar pengupahan akan menciptakan kepuasan kerja.

e. Opportunity of promotion, kesempatan promosi yang adil dan didasarkan pada kinerja dan senioritas (lama bekerja) akan meningkatkan kepuasan kerja

\section{Telaah Penelitian Sebelumnya}

Yuliansyah (2015) melakukan penelitian dengan judul Pengaruh Sistem Pengukuran Kinerja NonFinansial Terhadap Kinerja Anggota Kepolisian, Job Tension Sebagai Faktor Pemediasi. Penelitian ini bertujuan untuk menjelaskan pengaruh sistem pengukuran kinerja non-keuangan, job tension, terhadap kinerja anggota kepolisian. Penelitian dilakukan di institusi kepolisian di Provinsi Lampung dengan jumlah sampel sebanyak 160 responden dan dilakukan analsis data menggunakan program SmartPLS. Hasil penelitian menunjukkan bahwa pengukuran kinerja non-keuangan akan menurunkan job tension dan akan berpengaruh terhadap peningkatan kinerja individu. Hasil analisis perbandingan antara pengaruh langsung dan pengaruh tidak langsung terhadap kinerja polisi, menemukan bahwa pengaruh langsung Sistem Pengukuran Kinerja Non Finansial terhadap Kinerja Karyawan lebih tinggi dibandingkan pengaruh tidak langsung melalui job tension.

Yuliansyah dan Razimi (2015) dengan judul Non-financial performance measures and managerial performance: the mediation role of innovation in an Indonesian stock exchangelisted organization. Penelitian ini bertujuan untuk mengetahui pengaruh sistem pengukuran kinerja non-keuangan (NF) terhadap kinerja individual melalui inovasi dalam suatu perusahaan yang terdaftar di Bursa Efek Indonesia.Teknik analisis data menggunakan SmartPLS. Hasil penelitian menemukan bahwa sistem pengukuran kinerja NF memiliki pengaruh positif terhadap kinerja individu dan variabel inovasi merupakan mediasi penuh (fully mediated) hubungan sistem pengukuran kinerja non finansial terhadap kinerja individu.

Ruhana (2015) melakukan penelitian dengan judul Pengaruh Penilaian Kinerja Terhadap Kepuasan Kerja Dan Prestasi Kerja (Studi Pada Karyawan PT. Telekomunikasi Indonesia, Tbk Wilayah Malang).Tujuan dari penelitian ini adalah untuk mendeskripsikan penilaian kinerja, kepuasan kerja dan prestasi kerja, mengetahui dan menganalisis pengaruh penilaian kinerja terhadap kepuasan kerja secara signifikan, mengidentifikasi dan menganalisis pengaruh kepuasan kerja terhadap prestasi kerja secara signifikan, mengidentifikasi pengaruh penilaian kinerja terhadap prestasi kerja secara signifikan. Jenis penelitian yang digunakan adalah penelitian penjelasan (explanatory research) dengan pendekatan kuantitatif. Sampel pada penelitian ini adalah 63 responden menggunakan teknik propotionale random 
sampling. Berdasarkan hasil analisis jalur, dapat diketahui bahwa variabel penilaian kinerja berpengaruh secara signifikan terhadap variabel kepuasan kerja dengan nilai Beta 0.885 atau 88,5\% sedangkan sisanya $11,5 \%$ dipengaruhi oleh variabel lain yang tidak diperhitungkan dalam penelitian ini. Variabel kepuasan kerja berpengaruh secara signifikan terhadap variabel prestasi kerja dengan nilai Beta 0.479 atau $47,9 \%$ sedangkan sisanya adalah 52,1\% dipengaruhi oleh variabel lain yang tidak diperhitungkan dalam penelitian ini. Variabel penilaian kinerja berpengaruh secara signifikan terhadap variabel prestasi kerja dengan nilai Beta 0.443 atau 44,3\% sedangkan sisanya adalah 55.7\% dipengaruhi oleh variabel lain yang tidak dihitung dalam penelitian ini.

\section{METODE PENELITIAN}

Variabel penelitian ini dibagi menjadi 3 jenis variabel yaitu variabel independen yang terdiri dari sistem pengukuran kinerja variabel dependen adalah kinerja financial dan non financial pegawai dan variabel mediasi yaitu kepuasan kerja. Pengukuaran variabel ini menggunakan skala Likert digunakan untuk mengukur sikap, pendapat dan persepsi seseorang atau kelompok tentang kejadian atau gejala sosial. (Riduwan, 2010) skala linkert memiliki 5 alternatif pilihan, yaitu: STS : Sangat Tidak Setuju, TS : Tidak Setuju, N : Netral, S : Setuju, SS : Sangat Setuju. Nilai masing masing setiap jawaban diberi nilai berdasarkan skala linkert adalah sebagai berikut :

\begin{tabular}{|c|c|}
\hline Sangat Tidak Setuju & (STS) \\
\hline Tidak Setuju & (TS) \\
\hline Netral & $(\mathrm{N})$ \\
\hline Setuju & (S) \\
\hline Sangat Setuju & $(\mathrm{SS})$ \\
\hline
\end{tabular}

Hubungan model kausalitas membutuhkan alat analisis yang mampu menjelaskan hubungan tersebut, dengan demikian alat analisis yang digunakan dalam penelitian ini adalah metode Structural Equation Modelling (SEM). Model multilevel bisa diestimasi dengan menggunakan model persamaan structural (Ferdinand 2002). Hubungan model kausalitas penelitian ini merupakan hasil justifikasi secara teoritis dari berbagai sumber yang didukung oleh hasil kajian empiris, sehingga terbentuk sebuah model penelitian. Model penelitian ini menunjukkan hubungan kausalitas antar variabel. Hubungan kausalitas di antara variabel perlu diuji untuk mengkonfirmasi model melalui uji empiris.Untuk menguji sebuah teori, mungkin sebuah teori yang baru dikembangkan sendiri oleh peneliti, atau teori yang sudah dikembangkan sejak lama, pokoknya harus berupa sebuah teori, dan untuk pembuktiannya dibutuhkan sebuah pengujian empiris (Ferdinand 2002).

Pengujian terhadap model dikembangkan dengan berbagai kriteria Goodness of Fit, yakni Chisquare, Probability, RMSEA, GFI, dan TLI.

Tabel 1 Kriteria Goodness of Fit, yakni Chi-square, RMSEA, GFI, dan TLI)

\begin{tabular}{|c|c|c|}
\hline $\begin{array}{l}\text { GOODNESS OF } \\
\text { FIT INDEX }\end{array}$ & KETERANGAN & CUT OFF VALUE \\
\hline $\mathrm{X}^{2}-$ Chi square & $\begin{array}{l}\text { Menguji apakah covariance populasi yang diestimasi sama dengan covariance } \\
\text { sample (apakah model sesuai dengan data) (Haire et al., 1998) }\end{array}$ & $\begin{array}{l}\text { Diharapkan kecil, lebih } \\
\text { kecil dari nilai } \mathrm{X}^{2} \text { tabel }\end{array}$ \\
\hline Probability & $\begin{array}{l}\text { Uji signifikansi terhadap perbedaan matriks covariance data dan matriks } \\
\text { covariance yang diestimasi (Hair et al., 1998) }\end{array}$ & $\geq 0,05$ \\
\hline RMSEA & Mengkompensasi kelemahan Chi-square pada sample besar (Hair et al., 1995) & $\leq 0,08$ \\
\hline GFI & $\begin{array}{l}\text { Menghitung proporsi tertimbang varians dalam matriks sampel yang } \\
\text { dijelaskan oleh matriks covariance populasi yang diestimasi (analog dengan } \\
\mathrm{R}^{2} \text { dalam regresi berganda) (Bentler, 1983) }\end{array}$ & $\geq 0,90$ \\
\hline AGFI & GFI yang disesuaikan terhadap DF (Arbukle, 1999) & $\geq 0,90$ \\
\hline CMIN/DF & Kesesuaian antara data dengan model & $\leq 2,00$ \\
\hline TLI & $\begin{array}{l}\text { Pembandingan model yang diuji terhadap baseline model (Hair, 1995, } \\
\text { Arbukle, 1997) }\end{array}$ & $\geq 0,95$ \\
\hline CFI & $\begin{array}{l}\text { Uji kelayakan model yang tidak sensitive terhadap besarnya sample dan } \\
\text { kerumitan model (Arbukle, 1997) }\end{array}$ & $\geq 0,94$ \\
\hline
\end{tabular}

Sumber :Ferdinan (2002) 
Adapun model persamaan Strukturalnya adalah sebagai berikut:

$$
\begin{aligned}
& \mathrm{VP}=\beta 1 \mathrm{SFN}+\mathrm{e} 1 \\
& \mathrm{KK}=\beta 2 \mathrm{SFN}+\mathrm{e} 2 \\
& \mathrm{KJ}=\beta 1 \mathrm{VP}+\lambda 2 \mathrm{KK}+\mathrm{e} 3
\end{aligned}
$$

Keterangan :

$$
\begin{array}{ll}
\mathrm{M} & =\text { Value Perusahaan } \\
\mathrm{SFN} & =\text { Sistem pengukuran kinerja } \\
\mathrm{KK} & =\text { Kepuasan kerja } \\
\mathrm{KJ} & =\text { Kinerja pegawai } \\
\mathrm{e} & =\text { error } \\
\beta & =\text { koefisien path variabel eksogen terhadap endogen } \\
\lambda & =\text { koefisien path variabel endogen terhadap endogen }
\end{array}
$$

Uji hipotesis dilakukan untuk mengetahui apakah hipotesis yang telah disusun diterima atau ditolak. Dalam penelitian ini, uji hipotesis dilakukan menggunakan SEM AMOS. Pengujian hipotesis ini dilakukan dengan menganalisis nilai C.R (Critical Ratio) dan nilai P (Probability) dengan batasan statistik yang disyaratkan yaitu nilai CR (Critical Ratio) di atas 1,96 dan nilai P (Probability) di bawah 0.05.

\section{ANALISIS DAN PEMBAHASAN}

\section{Hasil Uji Pilot Test}

\section{Uji Validitas}

Hasil perhitungan koefisien korelasi $\left(r_{\mathbf{x y}}\right)$ untuk pengukuran kinerja non finansial 9 item pertanyaan, kepuasan kerja sebanyak 20 item dan prestasi kerja 9 pertanyaan yang nilainya diatas $r$ tabel $(0,3)$ sehingga seluruh item pertanyaan dinyatakan valid.

\section{Hasil Uji Reliabilitas}

Hasil uji reliabilitas diperoleh koefisien reliabilitas untuk seluruh variabel yang digunakan dalam penelitian ini lebih besar dari nilai kritisnya yaitu 0,6. Dengan demikian mengacu pendapat Nunnaly dalam Ghozali (2005), sehingga dapat disimpulkan bahwa seluruh butir pertanyaan yang tertuang dalam kuesioner penelitian ini dapat dinyatakan handal / reliabel. Artinya kuesioner ini memiliki hasil yang konsisten jika dilakukan pengukuran dalam waktu dan model atau desain yang berbeda.

\section{Uji Kelayakan Indikator}

\section{Analisis Structural Equation Model}

Analisis kuantitatif yang digunakan dalam penelitian ini adalah analisis Structural Equation Model. Model analisis jalur ini digunakan analisis SEM (Structural Equation Model) yaitu sekumpulan teknikteknik statistikal yang memungkinkan pengujian sebuah rangkaian hubungan yang relatif rumit secara simultan. Analisis dilakukan dengan program LISREL8.8. Analisis ini dipilih untuk mengetahui Pengaruh kinerja non finansial terhadap kinerja pegawai dengan motivasi dan kepuasan kerja sebagai variabel intervening Pada Kantor Wilayah Kementerian Hukum dan HAM Lampung.. Analisis ini sekaligus untuk membuktikan hipotesis penelitian ini yang telah dipaparkan pada bab sebelumnya.

\section{Uji Kecocok Model (Goodness of Fit)}

Nilai $\mathrm{X}^{2}-$ Chi Square dengan tingkat signifikansi sebesar 0,000 yang nilainya $\mathrm{p}<0,05$. Hal ini menunjukkan bahwa Ho yang menyatakan tidak terdapat perbedaan antara matrik kovarians sampel dengan matrik kovarians populasi yang diestimasi tidak dapat diterima. Artinya matrik kovarians sampel dengan matriks kovarians populasi yang diestimasi adalah tidak sama, sehingga model dinyatakan tidak fit. Goodness of Fit Indices (GFI) merupakan suatu ukuran mengenai ketepatan model dalam menghasilkan 
observed matriks kovarians. Tingkat penerimaan yang direkomendasikan GFI >0,90. Hasil menunjukkan nilai GFI sebesar $0,73<0,9$, sehingga model memiliki fit yang marginal.

Adjusted Goodness of fit Index - AGFI sebagai pengembangan indeks GFI, merupakan indeks yang telah disesuaikan dengan rasio degree of freedom model yang diusulkan dengan dengan degree of fredom dari null model. Hasil penelitian menunjukkan nilai AGFI sebesar 0,66 yang nilainya mendekati dari nilai AGFI yang direkomendasikan > 0,9, sehingga menunjukkan bahwa model ini memiliki fit yang marginal (cukup baik).

The Root Mean Square Error of Approximation - RMSEA; mengukur penyimpangan nilai parameter pada suatu model matriks kovarians populasinya. Nilai RMSEA menunjukkan goodnes of fit yang dapat diharapkan bila model diestimasi dalam populasi. Nilai penerimaan yang direkomendasikan $\leq$ 0,080, sementara hasil pengujian sebesar 0,078 yang menunjukkan bahwa model adalah baik. Ex Expected Cross Validation Index) ECVI digunakan untuk menilai kecenderungan bahwa model, pada sampel tunggal, cross validates (dapat divalidasi silang) pada ukuran sampel dan populasi yang sama. Hasil ECVI model adalah sebesar 6,85 sedangkan ECVI Saturated Model adalah sebesar 8,12. Dengan demikian ECVI model lebih rendah daripada ECVI Saturated Model, sehingga dapat disimpulkan bahwa model baik untuk direplikasi untuk penelitian berikutnya.

Aikake's Information Criterion AIC digunakan untuk menilai mengenai masalah parsimony dalam penilaian model fit. Hasil AIC model adalah sebesar 684,64 sedangkan AIC Saturated sebesar 812,00. Dengan demikian AIC model lebih kecil dari AIC Saturated, sehingga model dapat dinyatakan fit. NonNormed Fit Index (NNFI) digunakan untuk mengatasi permasalahan yang timbul akibat kompleksitas model. Hasil penelitian menemukan NNFI sebesar 0,92>0,9 sehingga model dapat dinyatakan fit.

Comparative Fit Index - CFI, merupakan indeks kesesuaian incremental yang membdaningkan model yang diuji dengan model null. Nilai yang direkomendasikan CFI $\geq 0,9$.

Hasil pengujian sebesar 0,93, menunjukkan bahwa model adalah baik Dari hasil pengukuran Goodness of Fit Index di atas, dapat disimpulkan sebagian besar parameter telah memenuhi persyaratan yang diharapkan, dan hanya parameter saja yaitu Chi Square yang memiliki nilai probabilitas < 0,05, GFI $<0,9$ dan AGFI<0,9. Namun menurut Ghozali (2005: 42) menyatakan bahwa hal tersebut tidak menjadi masalah karena itu dicari ukuran model fit yang lain. Ditinjau dari nilai RMSEA, ECVI, AIC, NNFI dan CFI telah memenuhi persyarakat goodness of fit.

\section{Hasil Pengujian Hipotesis}

\section{Pengaruh Pengukuran kinerja non finansial terhadap Prestasi Kerja}

Sebelumnya telah dikemukakan hipotesis alternatif pertama bahwa "Terdapat pengaruh positif penilaian kinerja non finansial terhadap prestasi kerja" Hasil pengujian dengan analisis LISREL 8.8 dapat diketahui pengaruh langsung pengukuran kinerja non finansial terhadap motivasi kerja memiliki koefisien jalur sebesar 0,42 dan $t_{\text {hitung }}$ sebesar 3,25>1,96 sehingga hubungan tersebut signifikan. Koefisien path positif menunjukkan bahwa pengukuran kinerja non finansial berpengaruh positif dan signifikan terhadap motivasi kerja pegawai. Artinya semakin baik sistem pengukuran kinerja non finansial maka semakin tinggi pula prestasi kerja, sehingga hipotesis pertama didukung.

\section{Pengaruh Pengukuran kepuasan kerja terhadap Prestasi kerja}

Hipotesis kedua penelitian ini menyatakan"Terdapat pengaruh positif penilaian kepuasan kerja terhadap prestasi kerja”. Hasil pengujian dengan analisis LISREL 8.8 dapat diketahui pengaruh langsung pengukuran kinerja non finansial terhadap kepuasan memiliki koefisien jalur sebesar 0,32 dan t hitung sebesar 3,39>1,96 sehingga hubungan tersebut signifikan. Nilai koefisien jalur positif menunjukkan bahwa pengukuran kepuasan kerja berpengaruh positif dan signifikan terhadap prestasi kerja pegawai. Artinya semakin meningkatnya kepauasan kerja maka semakin tinggi prestasikerja pegawai dan sebaliknya. Dengan demikian hipotesis kedua penelitian ini didukung.

Hasil penelitian ini didukung dengan pendapat Hasibuan (2003:88) bahwa alasan untuk melakukan 
penilaian kinerja adalah untuk meningkatkan tingkat kepuasan kerja karyawan dengan memberikan pengakuan terhadap hasil kerja mereka. Selain itu, hal ini juga dibuktikan oleh hasil penelitian yang dilakukan oleh Maria dalam Januarti dkk (2015), yaitu dengan adanya penerapan sistem penilaian kinerja yang efektif diharapkan akan meningkatkan kepuasan kerja karyawan yang secara langsung berpengaruh terhadap kinerja perusahaan maupun pengembangan karir karyawan. Penilaian Kinerja adalah salah satu metode yang dapat digunakan oleh perusahaan untuk mengetahui dan menilai seberapa besar kepuasan kerja karyawan akan pekerjaannya dan lingkungan kerjanya. Alasan penilaian dilakukan adalah untuk meningkatkan tingkat kepuasan kerja para karyawan dengan memberikan pengakuan terhadap hasil kerja mereka (Hasibuan, 2003). Penilaian kepuasan kerja karyawan akan dapat dipahami melalui sikap individu terhadap pekerjaan yang dilakukan, semakin banyak aspek dalam pekerjaan yang sesuai dengan keinginan individu maka semakin tinggi tingkat kepuasan yang dirasakan. Hasil penelitian mendukung penelitian Januarti dkk (2015) yang menemukan bahwa Kepuasan Kerja pada PT. Telekomunikasi Indonesia, Tbk Wialayah Malang dipengaruhi oleh Penilaian Kinerja sebesar 88,5\%, sedangkan sisanya yaitu sebesar $11,5 \%$ dipengaruhi oleh variabel lain yang tidak diperhitungkan pada penelitian ini.

\section{E. SIMPULAN DAN SARAN}

\section{Simpulan}

Berdasarkan hasil penelitian seperti yang telah diuraikan sebelumnya dapat ditarik beberapa kesimpulan yaitu :

1. Pengukuran kinerja non finansial berpengaruh positif dan signifikan terhadap prestasi kerja pegawai negeri di Lampung. Artinya semakin baik sistem pengukuran kinerja non finansial maka semakin tinggi pula prestasi kerjanya.

2. Pengukuran kepuasan kerja berpengaruh positif dan signifikan terhadap prestasi kerja pegawai. Artinya semakin meningkat kepuasan kerja pegawai maka semakin tinggi prestasi kerja pegawai.

\section{Saran}

Berdasar kesimpulan, selanjutnya dapat diusulkan saran yang diharapkan akan bermanfaat bagi pegawai negeri sipil di Lampung. Peningkatan pengukuran kinerja non finansial terutama pada indikator yang dinilai paling rendah oleh pegawai yaitu mengenai hubungan pegawai dengan Layanan tuntutan pengadilan, (misalnya, Mengisi tarif, tingkat keyakinan, proses pengadilan). Hal ini perlu adanya standar pelayanan dan standar tarif yang ditetapkan, dan bersifat transparan, serta komunikasi yang selalu terjalin dengan baik antar bagian/departemen yang ada termasuk pada bagian layanan pengadilan dengan pegawai secara umum.

\section{REFERENSI}

Arikunto,1996, Prosedur Penelitian Suatu Pendekatan Praktek. Jakarta: Rineka Cipta

As'ad, M, (2008). Seri Ilmu Sumber Daya Manusia: Psikologi Industri. Edisi keempat Liberty. Yogyakarta

Bernardin, H. John, dan Joyce E.A Russel. (2003). Human resource management (An Experimental Approach International Edition). Mc. Graw-Hill Inc. Singapore

Bowen, D.E. and Lawler, E.E., 1992,. The empowerment of service workers: what, why, how, and when, Sloan Management Review, 33 (3) : 31-39.

Davis, Keith dan Newstrom, 2000, Perilaku Dalam Organisasi, Edisi ketujuh, Penerbit Erlangga, Jakarta

Ciptani, Monika Kussetya. 2000. Balanced Scorecard Sebagai Pengukuran Kinerja Masa Depan: Suatu Pengantar. Jurnal akuntansi dan keuangan, Vol.2 ,No.1

Ferdinand, Augusty. 2002. Structural Equation Modelling dalam Penelitian. Manajemen. Semarang:FE UNDIP Filippo, Edwin, B. 1994. Manajemen Personalia.Terjemahan oleh Moh.Masud.Edisi keenam. Erlangga, Jakarta Fraser T.M, 1993, Human Stress, Work and Satisfaction, Jakarta: Pustaka Binaman Persindo

Ghozali, Imam. 2011. Model Persamaan Struktural dan Aplikasi dengan Program. Amos 21.Semarang: Badan Penerbit Universitas Diponegoro

Ghozali, Imam. 2001. Aplikasi Analisis Multivariate Dengan Program SPSS. Semarang: Badan Penerbit Universitas Diponegoro

Hasibuan. ( 2010). Manajemen Sumber Daya Manusia. Jakarta: Bumi Aksara. 
Hall, Matthew. 2008. The Effect of Comperhensif Performance Measurement System on Role Clarity, Psychological Empowerment and Managerial Performane. Accounting, Organizations and Society 33 (2-3): 141-163

Indriantoro, nurdan Supomo, bambang (1999).Metodologi Penelitian Bisnis Untuk. Akuntansi \& Manajemen. Yogyakarta : Penerbit BPFE.

Ivancevich, John, M, dkk. 2008. Perilaku dan Manajemen Organisasi, jilid 1 dan 2 Jakarta : Erlangga

Januari Cindi Ismi, Hamidah Nayati Utami, Ika Ruhana (2015), Pengaruh Penilaian Kinerja Terhadap Kepuasan Kerja Dan Prestasi Kerja (Studi pada Karyawan PT. Telekomunikasi Indonesia, Tbk Wilayah Malang), Jurnal Administrasi Bisnis (JAB)|Vol. 24 No. 2

Kaplan, R.S., and D.P. Norton., 1992. The Scorecard: Measures That Drive Performance. Harvard Business Review 70: 71-79.

Kaplan, Robert S. and David P. Norton, 2000.Balanced Scorecard : Menerapkan Strategi Menjadi Aksi, Erlangga : Jakarta

Lau Chong M. And Brigitte Oger, 2012, An empirical study of the effects of nonfinancial performance measures on employee behaviours, UWA Business School The University of Western Australi

Liliweri Alo. 1997. Komunikasi Antarpribadi, Bandung, PT. Citra Aditya Bakti

Lawler, E. E., 1992. The Ultimate Advantage: Creating the High Involvement Organization. San Francisco, CA: Jossey-Bass.

Lau, C.M., \& Sholihin, M. 2005. Financial and Nonfinancial Performance Measures: How do They Affect Job Satisfaction? The British Accounting Review, vol 37 (4): 401

L.Lynch Richard \& F.Cross, 1993, Performance Measurement System, Handbook of Cost Management, Edisi Ketiga, New York

Luthans, F. (2005).Perilaku Organisasi, Edisi 10. Yogyakarta: Andi.

Mahsun, Mohamad, 2006. Pengukuran Kinerja Sektor Publik, Penerbit BPFE,Yogyakarta

Martoyo Susilo, 2007, Manajemen Sumber Daya Manusia, Edisi 5, Yogyakarta: BPFE

Mawarni Sri, Yuliansyah (2015), Pengaruh Sistem Pengukuran Kinerja Non-Finansial Terhadap Kinerja Anggota Kepolisian, Job Tension Sebagai Faktor Pemediasi, Jurnal SNA XVIII Medan

Riduwan, 2010.Skala Pengukuran Variabel-Variabel Penelitian. Alfabeta, Bandung

Robbins Stephen P., 1996. Perilaku Organisasi, Konsep, Kontroversi danAplikasi. Alih Bahasa : Hadyana Pujaatmaka. Edisi Keenam. Penerbit PT.Bhuana Ilmu Populer, Jakarta

Robbins, Stephen P, (2006). Perilaku Organisasi Edisi Bahasa Indonesia.Trj. Benyamin Molan. Jakarta: PT. Indeks, Kelompok Gramedia

Siagian, Sondang.S., 1997, Manajemen sumber daya manusia. Jakarta: Penerbit,Bina Aksara.

Sinulingga Monica Carolina, Yuliansyah, Oktavia Reni, 2013, Pengaruh Pengukuran Kinerja Non-Keuangan Terhadap Kinerja Karyawan: Motivasi Intrinsik Dan Ekstrinsik Sebagai Faktor Pemediasi (Studi Kasus di Kepolisian Kota Bandar Lampung), e-journal Unila

Solimun.2002, Multivariate Analysis Structural Equation Modelling (SEM) Lisrel dan Amos. Fakultas MIPA, Universitas Brawijaya

Sudarmanto. 2009. Kinerja dan Pengembangan Kompetensi SDM (Teori, Dimensi Pengukuran dan Implementasi dalam Organisasi).Yogyakarta : Pustaka Pelajar

Sugiyono.(2009). Metode Penelitian Bisnis (Pendekatan Kuantitatif, Kualitatif, dan R\&D). Bandung: Alfabeta

Wibowo. 2007. Manajemen Kinerja. PT. Raja Grafindo Parsada: Jakarta

Wiyono Gendro. 2011. Merancang Penelitian Bisnis Dengan Alat Analisis SPSS 17.0 \& Smart PLS 2.0 : Percetakan STIM YKPM. Yogyakarta

Yuliansyah, Mohd Shahril Ahmad Razimi 2015, Non-financial performance measures and managerial performance: the mediation role of innovation in an Indonesian stock exchangelisted organization, Problems and Perspectives in Management, Volume 13, Issue 4, 2015

Yuwono, dkk. 2004. Balanced Scorecard: Menuju Organisasi Yang Berfokus Pada Strategi. PT. Gramedia Pustaka Utama: Jakarta.

Wibowo. 2011. Manajemen Kinerja. Edisi Ketiga. Jakarta: PT Raja Grafindo Persada.

Wong-On-Wing, B., Lan Guo, dan Gladie Lui, 2010. Intrinsic and Extrinsic Motivation and Participation in Budgeting: Antecedents and Consequences. Behavioral Research in Accounting Volume 22

PP No.46 tahun 2011 tentang Penilaian Prestasi Kerja Pegawai Negeri Sipil 